\title{
KAJIAN KONSEP ARSITEKTUR ANALOGI PADA BANGUNAN MUSEUM PURNA BHAKTI PERTIWI DAN MUSEUM KOMODO
}

\author{
${ }^{1}$ Muhammad Muslimin, ${ }^{2}$ Ashadi, ${ }^{3}$ Anisa \\ 1,2Universitas Muhammadiyah Jakarta, Jakarta, Indonesia \\ 2015460061@ftumj.ac.id ${ }^{1}$
}

Informasi Naskah

Diterima: 29/06/2020; Disetujui terbit: 29/12/2020; Diterbitkan: 29/12/2020; http://journal.uib.ac.id/index.php/jad

\begin{abstract}
ABSTRAK
Museum merupakan bangunan yang menyimpan benda-benda bersejarah, karya seni maupun benda yang bersifat edukasi lainnya. Penelitian pada museum ini bertujuan untuk mengetahui apa itu konsep arsitektur analogi dan bagaimana penerapan konsep arsitektur analogi pada bangunan museum. Metode penelitian yang digunakan adalah metode deskriptif kualitatif yaitu metode dengan menggunakan data yang ada dengan menggunakan landasan teori yang terkait baik secara arsitektural maupun non arsitektural, dimulai dari pengumpulan data sampai dengan pengolahan data secara faktual untuk mengetahui penerapan konsep arsitektur analogi pada bangunan museum. penerapan prinsip arsitektur analogi tidak semerta-merta menjiplak objek yang dianalogikan tetapi diperlukan proses-proses analisis dan merangkainya sehingga menghasilkan bentuk baru yang masih memiliki kemiripan visual dengan objek yang dianalogikan.
\end{abstract}

Kata Kunci: arsitektur analogi, museum, museum analogi

\begin{abstract}
Museum is a building that holds historical objects, artworks and other educational objects. This research about museum aims to find out what is the concept of analogy architecture and how to apply the concept of analogy architecture to the Museum building. The research method used is a qualitative descriptive method that is a method of using existing data using a theoretical basis related both architectural and non-architectural, starting from data collection to factual data processing to determine the application of the concept of analogy architecture in museum buildings. The application of the principle of analogy architecture does not necessarily plagiarize the object model that is analogous, but the processes of analysis and arrangement are needed to produce a new form that still has a visual resemblance to the object being analogized.
\end{abstract}

Keywords: architectural analogy, museum, museum of analogy

\section{Pendahuluan}

Di Indonesia, konsep Arsitektur analogi banyak digunakan para arsitek untuk merancang karyanya, selain dari segi estetika penerapan konsep analogi juga untuk menyampaikan sebuah pesan mendalam dari karyanya. Suatu pendekatan analogi dikatakan berhasil apabila pesan yang ingin disampaikan atau objek yang dianalogikannya dapat dipahami oleh semua orang. Oleh karena itu, harus terdapat benang merah antara bangunan dan objek yang dianalogikannya dalam proporsi tertentu sehingga tidak menjadi terlalu naif seperti menjiplak secara mentah-mentah. 
Hal yang penting dalam analogi adalah persamaan antara bangunan dengan objek yang dianalogikan. Persamaan di sini bukan berarti benar-benar serupa dengan objek dan hanya diperbesar ukurannya saja, tetapi yang dimaksudkan adalah persamaan berupa pesan yang disampaikan. Oleh sebab itu, analogi menjadi sangat berharga karena sifatnya yang sangat personal, berarti dapat dipahami oleh setiap orang.

Di Indonesia terdapat beberapa bangunan yang menerapkan konsep analogi diantaranya adalah museum, teater, monumen, dan lain-lain. Salah satu bangunan berkonsep analogi yang terkenal adalah Museum Purna Bhakti Pertiwi dan Museum Komodo yang berlokasi di Taman Mini Indonesia Indah. Perencana menggunakan pendekatan konsep analogi bentuk langsung pada objek berupa nasi tumpeng dan hewan Komodo. Hal ini membuat peneliti tertarik untuk melakukan penelitian lebih mendalam terhadap bangunan berkonsep analogi tersebut untuk kemudian di jadikan acuan dalam merancang bangunan dalam bentuk yang lain.

Tujuan dari penelitian terhadap konsep arsitektur analogi pada bangunan museum ini diantaranya adalah untuk mengetahui apa itu arsitektur analogi dan untuk mengetahui bagaimana penerapan kosep arsitektur analogi pada bangunan Museum Purna Bhakti Pertiwi dan Museum Komodo.

\section{Kajian Pustaka}

Konsep arsitektur analogi merupakan konsep yang cukup sering digunakan para arsitek dalam merancang karyanya. Agar lebih mudah memahami konsep arsitektur analogi berikut merupakan pengertian dari segi bahasa dan pengertian menurut beberapa ahli.

\section{Pengertian Arsitektur Analogi}

1. Pengertian analogi dalam KBBI adalah:

a. Persamaan antara dua benda atau hal yang berlainan.

b. Kesepadanan antara bentuk bahasa yang menjadi dasar terjadinya bentuk lain.

c. Sesuatu yang sama dalam bentuk, susunan, atau fungsi, tetapi berlainan asalusulnya sehingga tidak ada hubungan kekerabatan.

2. Analogi Menurut Geoffrey Broadbent

Menurut Broadbent (1973) “... Analogi merupakan suatu mekanisme sentral dalam menerjemahkan analisa ke dalam sintesa", maksud dari pernyataan ini adalah bahwa dalam pendekatan analogi bukan hanya menjiplak objek alam yang dianalogikan, akan tetapi perlu dilakukan analisis dan merangkainya sehingga menghasilkan bentuk baru yang masih memiliki kemiripan visual dengan objek yang dianalogikan.

Dalam buku Design in Architecture karya Broadbent, pendekatan analogi dibagi ke dalam tiga macam, yaitu analogi langsung, analogi personal, dan analogi simbolik.

\section{a. Analogi langsung}

Analogi ini digunakan untuk membandingkan suatu objek dengan beberapa fungsi bangunan yang didesain, dimana analogi tersebut digunakan untuk menstimulasi ide desain. Perbandingan tersebut digunakan untuk mengungkapkan aspek dari permasalahan desain yang belum terpecahkan pada bagian riset proyek tersebut, seperti yang terlihat pada gambar 1 . 


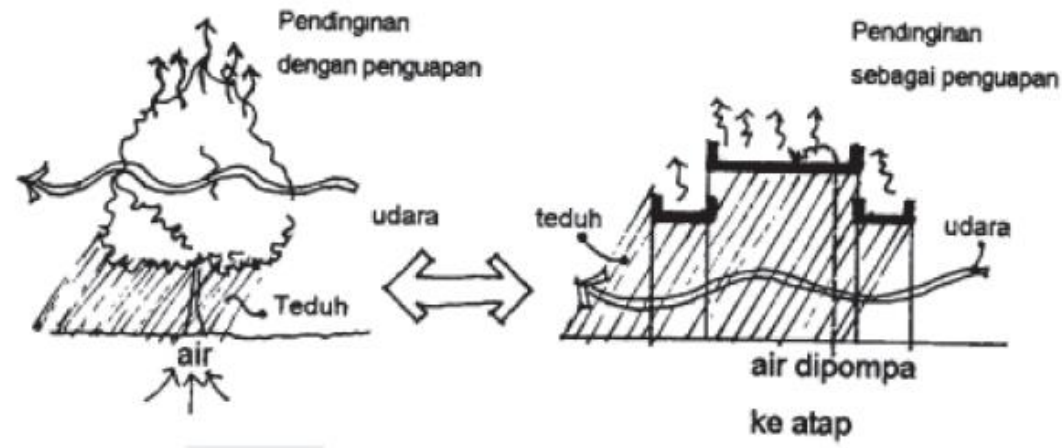

Gambar 1. Contoh Analogi Langsung

Sumber: Broadbent dalam Lucia Ina Trisjanti (2017)

b. Analogi personal

Analogi ini bergantung pada persepsi seseorang jika orang tersebut berada dalam obyek yang didesain, seperti pada gambar 2 .

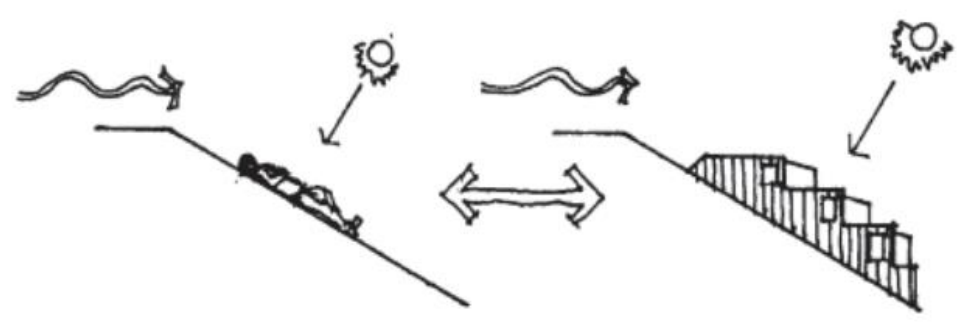

Gambar 2. Contoh Analogi Personal

Sumber: Broadbent dalam Lucia Ina Trisjanti (2017)

c. Analogi simbolik

Merupakan suatu pengibaratan dari sesuatu yang sudah dikenal secara umum, seperti yang terlihat pada gambar 3 .

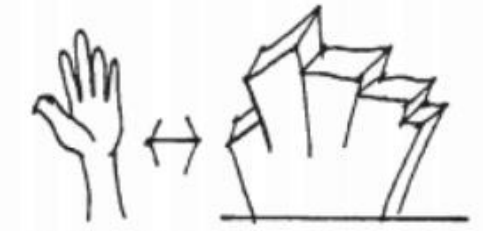

Telapak tangan

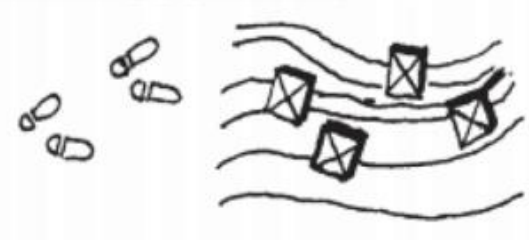

Jejak Kaki

Gambar 3. Contoh Analogi Simbolik

Sumber: Broadbent dalam Lucia Ina Trisjanti (2017)

\section{Analogi Menurut Karina Moraes Zarzar}

Analogi dapat digunakan dengan bermacam cara, salah satunya adalah sebagai alat komunikasi seseorang di dalam mengekspresikan pemikirannya secara tidak langsung. Suatu benda dikatakan analogi dengan benda lainnya apabila keduanya memiliki beberapa kesamaan. Analogi memiliki tiga hal dasar, yaitu kesamaan, struktur atau susunan, dan kegunaan. Analogi ditekankan untuk mengidentifikasi struktur atau sususan paralel antara sumber dan benda obyek. Setiap elemen benda obyek harus terhubung dengan hanya satu elemen pada 
sumber (dan sebaliknya) (Zarzar et al., 2008). Analogi digunakan jika berhubungan dengan pemindahan karakteristik dari suatu sumber ke suatu obyek atau proses. Terdapat dua jenis pemindahan karakteristik pada analogi, yaitu:

a. Hanya pada konfigurasi elemen-elemennya.

b. Penggunaan struktur atau susunan yang tidak sama dengan fungsi sumbernya.

4. Analogi Menurut Chris Abel (1997)

Sifat dasar dan fungsi dari karakter dari benda yang dijadikan sumber analogi harus benar-benar diteliti secara tepat. Terdapat tiga karakter analogi, yaitu:

a. Positif analogi, sifat dasar dan fungsi antara dua ide yang berbeda terlihat jelas.

b. Negatif analogi, sifat dasar dan fungsi antara dua ide yang berbeda tidak jelas.

c. Netral analogi, sifat dasar dan fungsi tidak spesifik di antara tiap ide yang berbeda, dalam hal ini perlu dicari lagi kesamaan dan perbedaan di antara keduanya.

\section{Prinsip Arsitektur Analogi}

Terdapat 3 prinsip arsitektur analogi yaitu:

1. Kemiripan visual dengan objek yang dijadikan perbandingan.

2. Berusaha mentransfer suatu keterangan seakan merupakan hal yang sama.

3. Tidak menimbulkan interpretasi lain.

\section{Metode Penelitian}

Metode yang digunakan dalam penelitian ini adalah metode penelitian kualitatif, yaitu sebuah metode yang sifatnya deskriptif. Dimana prosesnya menggunakan analisis, mengacu pada data yang dikumpulkan, dan memanfaatkan teori yang ada sebagai bahan pendukung, lalu menghasilkan suatu teori. Berikut adalah tahapan-tahapannya:

1. Pendataan

Dalam proses pendataan terdiri dari dua sumber yaitu studi literatur dan studi lapangan.

a. Studi Literatur

Studi literatur tentang arsitektur analogi menurut beberapa ahli, dari beberapa pendapat tersebut kemudian dikomparasikan antara satu dengan yang lainnya dan dicari kesamaannya untuk dijadikan acuan penelitian pada bangunan objek studi. Pengumpulan data melalui pengkajian literatur ini dapat ditempuh dengan membaca dan mengumpulkan teori yang ada. Dapat diperoleh dari berbagai sumber, seperti: jurnal, tesis, buku, artikel, skripsi, catatan harian, arsip foto dan literatur lainnya. Sumber literatur tersebut, dapat dilakukan dengan mengunjungi perpustakaan, toko buku, dan internet.

b. Studi lapangan

Pengumpulan semua data yang ada di lapangan, pengumpulan data dilakukan dengan cara mendokumentasikan kondisi di lapangan mencatat hal-hal yang di perlukan, sketsa, dan wawancara terhadap pengelola, dan dengan wawancara terhadap petugas pengelola. Dengan menggunakan seluruh panca indera kita, kita dapat melihat, merasakan, mendengar dan memahami secara langsung apa saja yang terdapat dilapangan. Hal ini berguna untuk memperoleh informasi guna menjawab permasalahan penelitian. Hasil yang didapat dari tinjauan langsung ke lapangan merupakan suatu aktifitas, perasaan emosi, detail kejadian, dan kondisi tertentu. Tinjauan lapangan dilakukan untuk memperoleh gambaran suatu peristiwa secara nyata sebagai acuan untuk menjawab semua pertanyaan penelitian.

136 I JAD- vol.01/No.02, Desember 2020 
2. Analisis Data

Berikut merupakan tahapan dalam analisa:

a. Merangkum teori-teori tentang arsitektur analogi.

b. Menganalisis penerapan konsep arsitektur analogi pada dua studi kasus.

- Mengidentifikasi dan mendeskripsikan objek penelitian terpilih terkait konsep arsitektur analogi.

- Menafsirkan kaitan prinsip-prinsip arsitektur analogi dengan hasil identifikasi terhadap dua studi kasus.

- Mendeskripsikan hasil analisis.

Untuk lebih jelas nya dapat dilihat pada gambar 4.

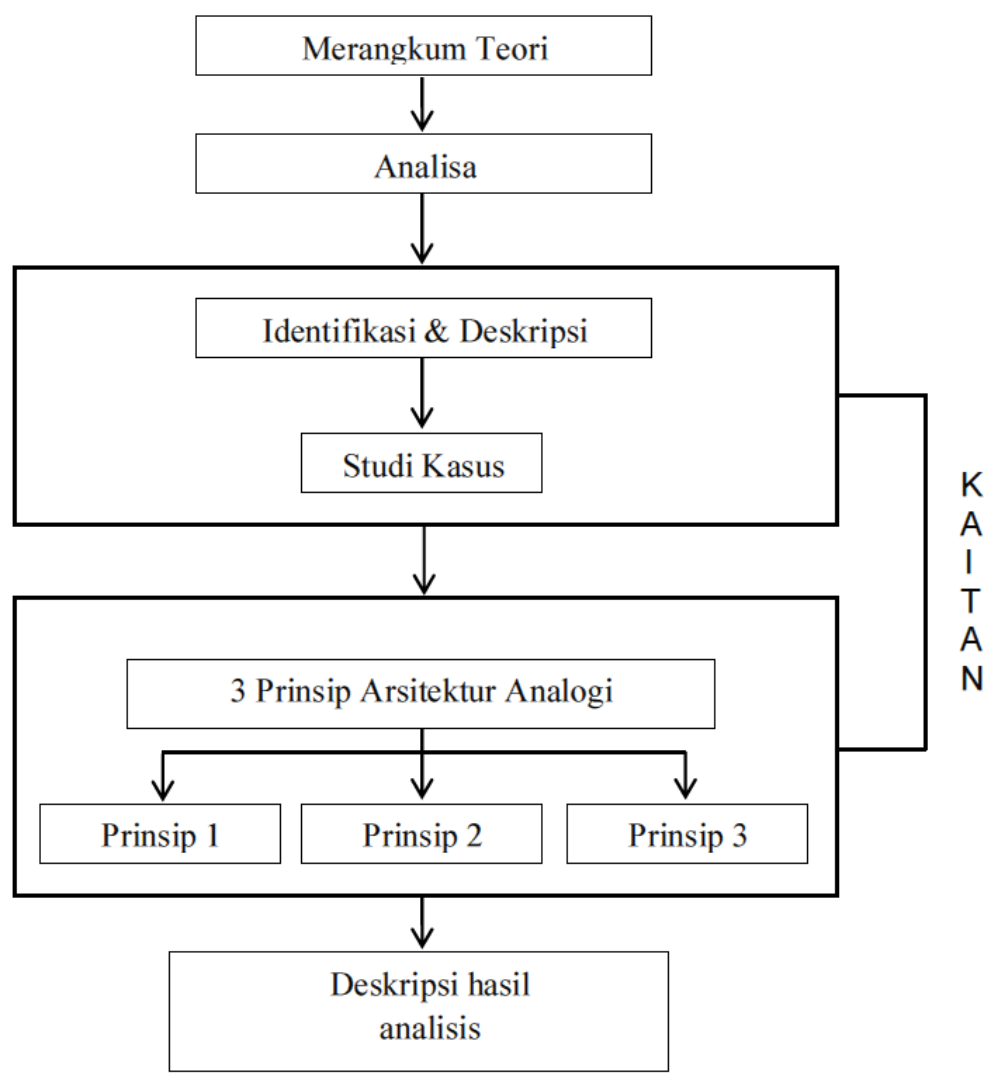

Gambar 4. Skema Proses Analisis

Sumber: Pribadi, 2019

\section{Hasil dan Pembahasan}

1. Museum Purna Bhakti Pertiwi

Museum Purna Bhakti Pertiwi didirikan oleh Yayasan Purna Bhakti Pertiwi atas prakarsa Ibu Tien Soeharto. Museum yang berada di JI. Taman Mini I, Jakarta 13560. Museum ini berisi koleksi benda-benda dan cenderamata berharga yang bersangkutpaut dengan perjalanan pengabdian Presiden Republik Indonesia Ke-2, Soeharto.

\section{Identifikasi dan deskripsi 1:}

Denah setiap masa bangunan berbentuk dari kumpulan masa berbentuk lingkaran yang tersusun rapi, di bagian pusat terdapat massa berbentuk lingkaran yang paling besar serta dikelilingi lingkaran-lingkaran yang lebih kecil, analoginya seperti hidangan nasi tumpeng besar yang dikelilingi nasi lauk-pauk, seperti yang terlihat pada gambar 5 . 


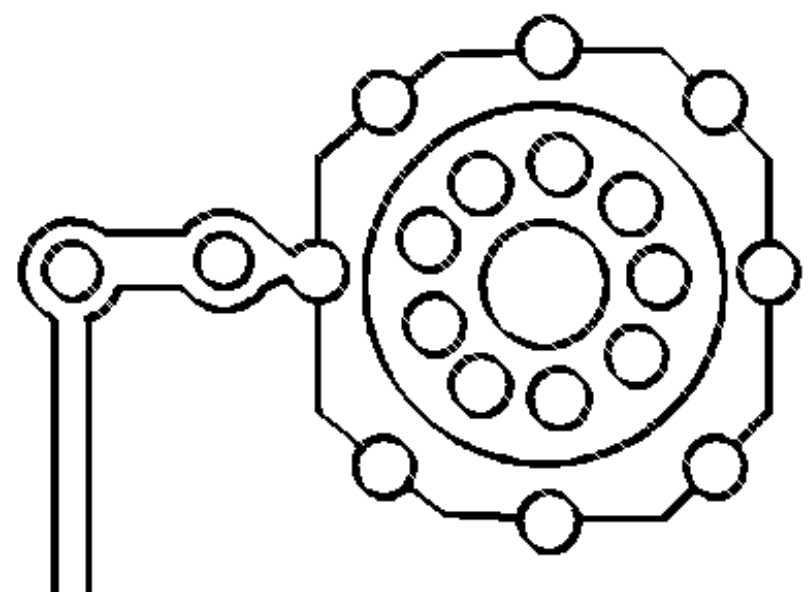

Gambar 5. Denah Massa Bangunan

Sumber: Pribadi, 2019

\section{Identifikasi dan deskripsi 2:}

Dilihat dari perspektif atas bangunan terlihat seperti kerucut yang disusun diatas sebuah benda pipih berbentuk bulat yang sangat mirip dengan suatu hidangan nasi tumpeng, seperti yang terlihat pada gambar 6 .

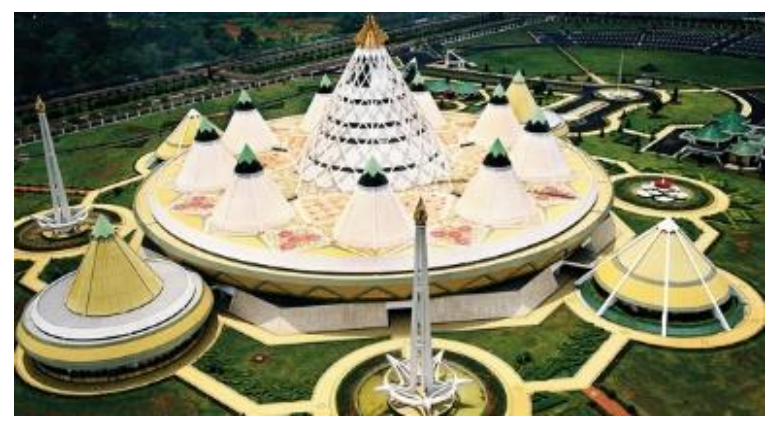

Gambar 6. Perspektif Bangunan Museum Purna Bhakti Pertiwi Sumber: tamanmini.com, -

\section{Identifikasi dan deskripsi 3:}

Fasad bangunan terlihat sangat jelas bentuknya berupa kerucut dengan topian kecil berwarna hijau diatasnya, mirip sepeti nasi tumpeng yang bagian atasnya ditutup benda berbentuk kerucut kecil berupa daun pisang yang di bentuk demikian. Seperti yang terlihat pada gambar 7 .

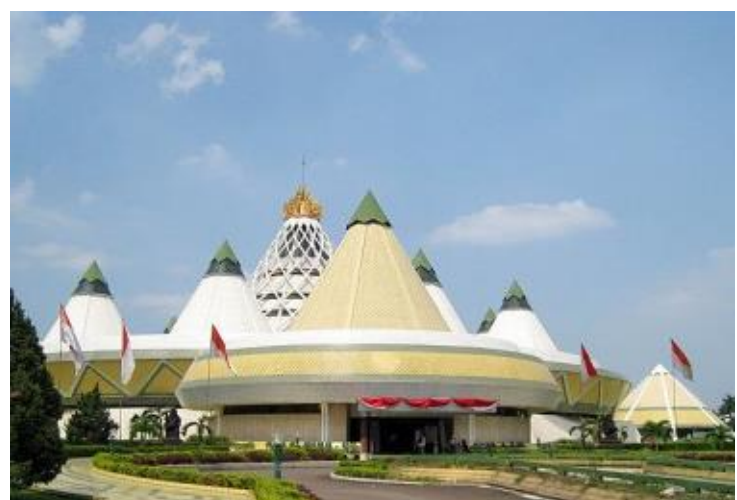

Gambar 7. Tampak Depan Bangunan Museum Bhakti Pertiwi Sumber: tamanmini.com, - 


\section{Museum Komodo}

Merupakan museum yang bertemakan dunia satwa Indonesia dalam bentuk awetan. Bangunan museum sangat unik karena ruang pameran berbentuk komodo, jenis reptil purba yang hidup di habitat aslinya Pulau Komodo, Nusa Tenggara Timur. Museum ini terletak di dalam lingkungan Taman Mini Indonesia Indah.

\section{Identifikasi dan deskripsi 1:}

Raut bangunan dari atas berbentuk seperti komodo yang sedang berjalan dengan kedua tangan dan kakinya dengan kepala yang bulat agak lonjong dan ekor yang meruncing, seperti yang terlihat pada gambar 8 .

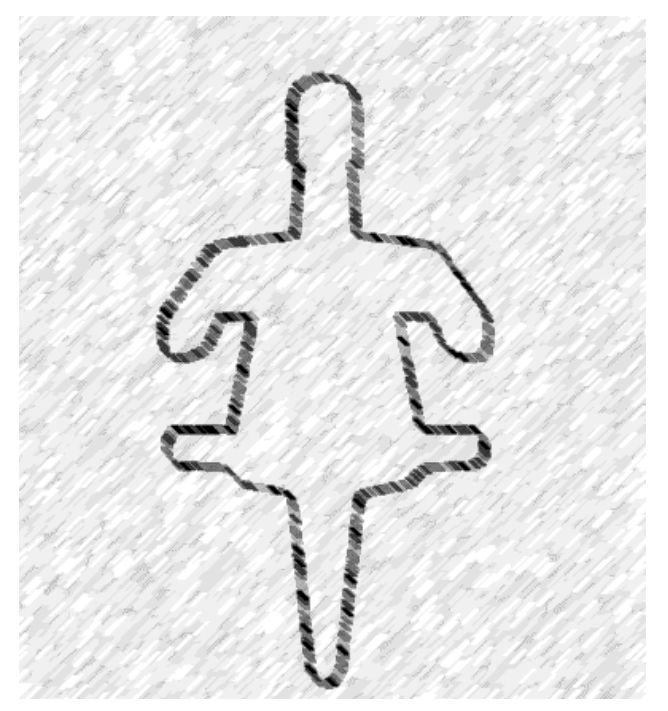

Gambar 8. Raut Museum Komodo dari Atas Sumber: Pribadi, 2019

\section{Identifikasi dan deskripsi 2:}

Dilihat dari perspektif samping bangunan terlihat menyerupai komodo dengan tubuh yang kekar lengkap dengan sisik yang dibentuk mirip dengan sisik pada umum nya dan tangan yang kokoh menapak ke kolam, seperti yang terlihat pada gambar 9 .

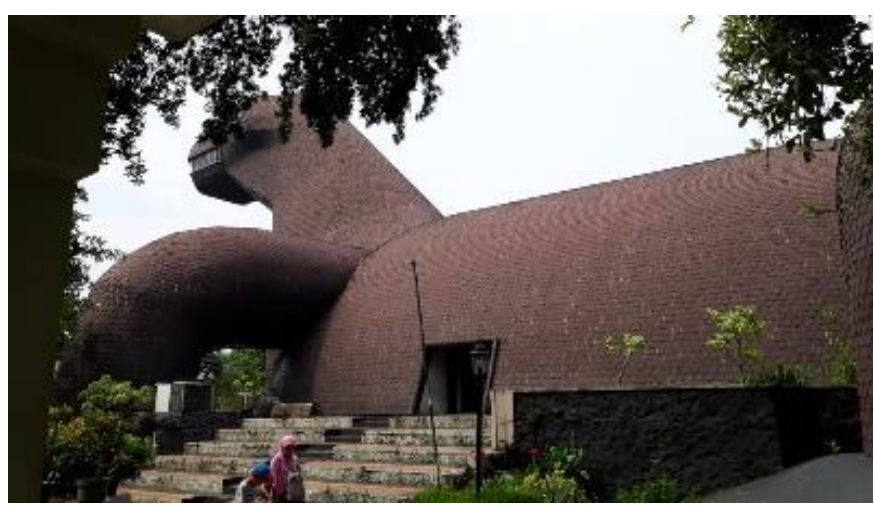

Gambar 9. Tampak Samping Museum Komodo Sumber: Pribadi, 2019

\section{Identifikasi dan deskripsi 3:}

Tampak bangunan menyerupai bentuk komodo dengan kepala yang memanjang dan leher yang tegap dengan posisi tubuh normal seperti komodo yang sedang berjalan, seperti yang terlihat pada gambar 10 . 


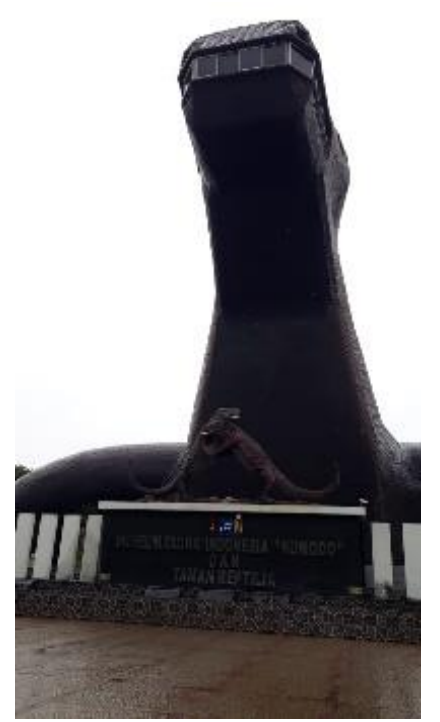

Gambar 10. Tampak Depan Museum Komodo Sumber: Pribadi, 2019

\section{Menafsirkan Kaitan Prinsip Arsitektur Analogi dengan Hasil Identifikasi dan Deskripsi Objek Penelitian}

\subsection{Museum Purna Bhakti pertiwi}

Tahap ini bertujuan untuk mencari keterkaitan antara prinsip arsitektur analogi dengan hasil identifikasi dan deskripsi terhadap studi kasus, sehingga dapat disimpulkan hasil analisis sebagai hasil akhirnya.

\section{a. Prinsip 1: kemiripan visual dengan objek yang dijadikan perbandingan}

Dari hasil identifikasi menunjukan bahwa kedua nya memiliki keterkaitan pada perletakan masa bangunan yang ketika diproyeksikan menjadi bentuk kerucut yang menyerupai susunan nasi tumpeng lengkap dengan ornamen-ornamen nya yaitu berupa lauk-pauk yang diwujudkan dengan kumpulan nasi tumpeng kecil yang mengelilingi nasi tumpeng besar ditengahnya, seperti yang terlihat pada gambar 11 .

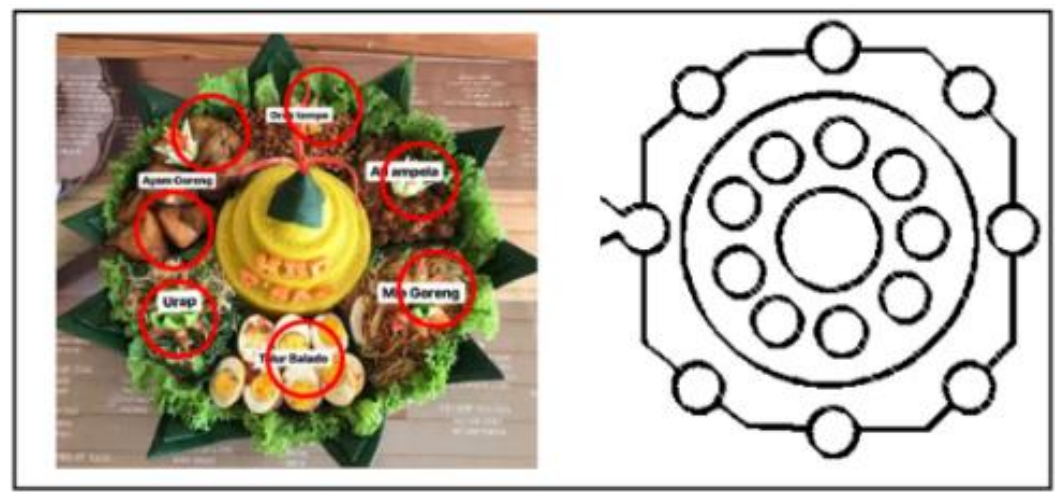

Gambar 11. Perbandingan perletakan masa bangunan dan perletakan nasi tupeng Sumber : Pribadi, 2019

Selain denah, kemiripan visual juga diwujudkan pada tampilan fasad bangunan yang di buat berupa bentuk masa yang sama yaitu kumpulan bentuk kerucut, seperti yang terlihat pada gambar 12 . 


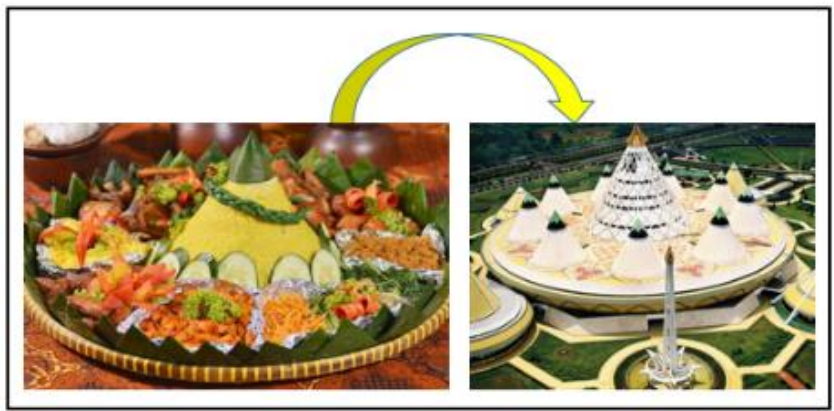

Gambar 12. Kemiripan visual nasi tumpeng dengan bangunan Sumber : Pribadi, 2020

\section{b. Prinsip 2: berusaha mentransfer keterangan seolah merupakan suatu hal yang sama}

Usaha mentransfer keterangan seolah menjadi hal yang sama diwujudkan dalam komposisi hidangan nasi tumpeng yaitu berupa kumpulan masa berbentuk kerucut yang disusun rapi mengelilingi kerucut paling besar yang berada ditengah. bagian tengah hidangan nasi tupeng pasti selalu besar dan dikelilingi bagian-bagian lain yang lebih kecil, Berikut adalah transformasi bentuk bangunan dengan objek yang dianalogikan, terlihat pada gambar 13.

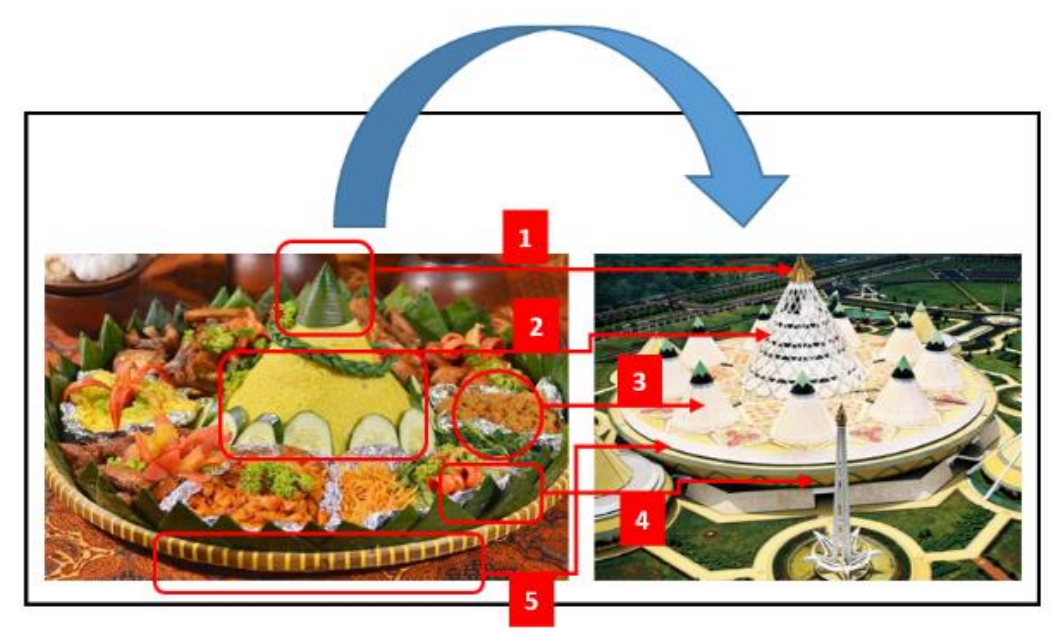

Gambar 13. Persamaan nasi tumpeng dengan bangunan

Sumber : Pribadi, 2019

Keterangan :

1.Daun penutup tumpeng $\rightarrow$ Mahkota bangunan

2. Nasi tumpeng paling besar $\rightarrow$ Badan masa paling besar

3. Lauk pauk $\rightarrow$ Masa kecil berbentuk kerucut

4. Daun hiasan $\rightarrow$ Ornamen dinding bangunan

5. Nampan $\rightarrow$ Dak bangunan

\section{c. Prinsip 3: tidak menimbulkan interpretasi lain}

Dari hasil wawancara dengan mahasiswa angkatan $15 \mathrm{UMJ}$, menunjukan bahwa mereka sepakat bahwa bangunan merupakan hal yang seakan sama yang merupakan hasil transformasi bentuk nasi tumpeng, seperti yang terlihat pada gambar 14. 


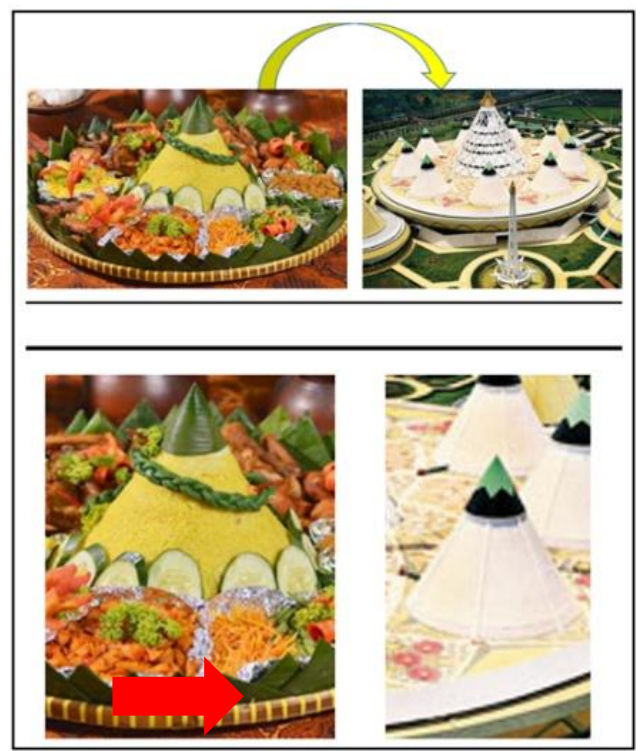

Gambar 14. Perbandingan Tampilan Bangunan dengan Objek Perbandingan Sumber : Pribadi, 2019

Terdapat banyak sekali persamaan diantara kedua nya sehingga orang akan dengan mudah mengerti dan berintepretasi maksud dari dua benda ini.

\subsection{Museum Komodo}

\section{a. Prinsip 1: kemiripan visual dengan objek yang dijadikan perbandingan}

Dari hasil identifikasi menunjukan bahwa salah satu kemiripan visualnya diwujudkan melalui tampilan raut bangunan yang menyerupai bentuk yang diharapkan yaitu hewan reptil berupa komodo, seperti yang terlihat ada gambar 15 .

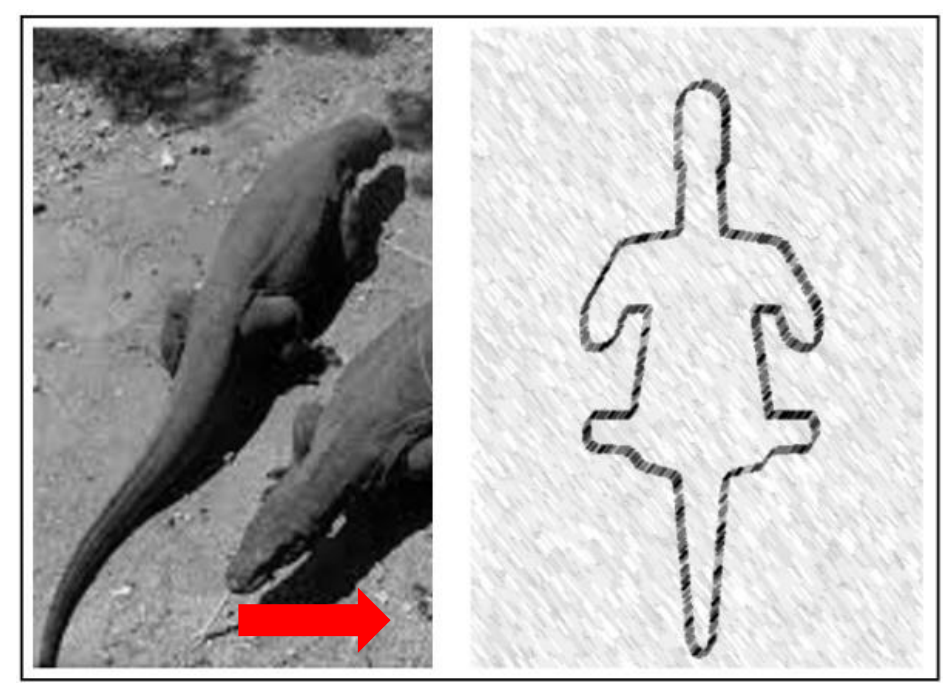

Gambar 15. Perbandingan Raut Museum dengan Bentuk Komodo dari Atas Sumber : Pribadi, 2019

Kemiripan visual lainnya ditunjukan pada tampilan fasad bangunan yaitu menyamakan bentuk anggota tubuh bagian atas dengan bangunann bagian atas, seperti yang terlihat pada gambar 16. 


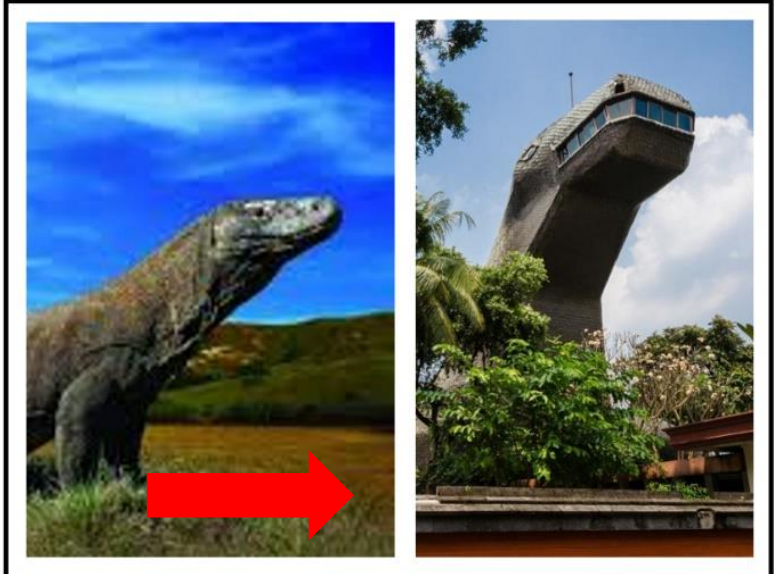

Gambar 16. Perbandingan Bentuk kepala komodo dengan Museum Komodo Sumber : Pribadi, 2019

\section{b. Prinsip 2: berusaha mentransfer keterangan seolah merupakan suatu hal yang} sama

Usaha mentransfer keterangan seolah merupakan hal yang sama diwujudkan melalui perwujudan seluruh bagian tubuh komodo menjadi bagian dari unsur-unsur yang melekat dalam bangunan itu sendiri mulai dari kepala hingga ujung ekor. Terlihat pada gambar 17.

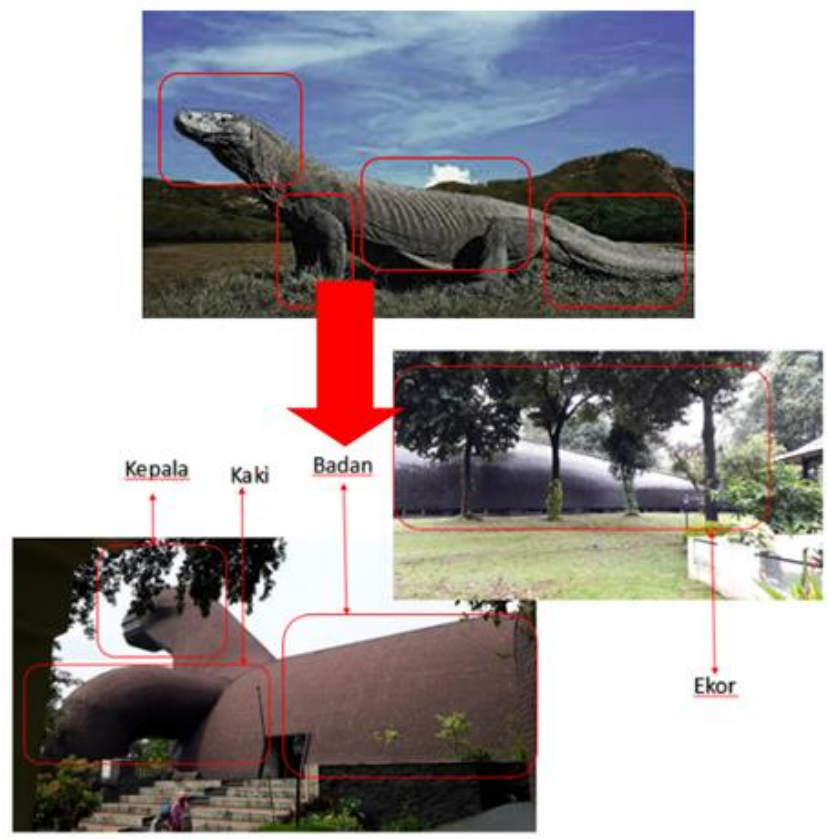

Gambar 17. Persamaan Museum Komodo dari Tampak Samping Sumber : Pribadi, 2019

Perwujudan bentuk diimplementasikan secara frontal dengan mengambil seluruh bagian objek yang dianalogikan kedalam bentuk bangunan secara menyeluruh.

\section{c. Prinsip 3: tidak menimbulkan interpretasi lain}

Bentuk komodo yang sangat melekat pada bangunan ini menjadi model dalam bangunan museum ini sehingga orang akan secara langsung mengatakan bahwa bangunan bangunan komodo, seperti yang terlihat pada gambar 18. 


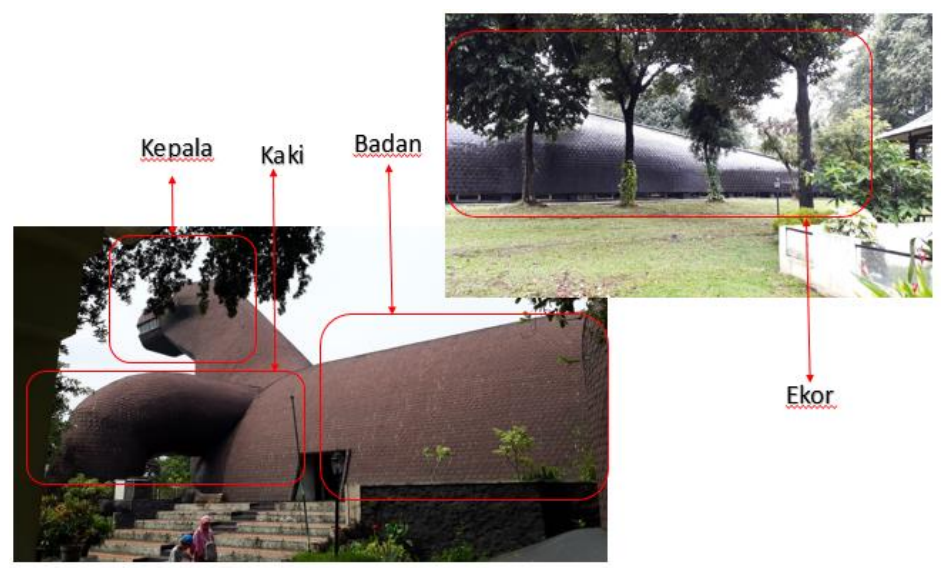

Gambar 18. Museum Komodo dari Tampak Samping Sumber : Pribadi, 2019

Persamaan bentuk diwujudkan secara frontal sehingga tidak sulit bagi orang awam untuk menilai persamaan dari keduanya.

\section{Deskripsi Hasil Analisis}

Penerapan konsep arsitektur analogi pada kedua bangunan Museum dapat dicapai melalui pengimplementasian prinsip-prinsip arsitektur analogi yaitu:

\section{a. Prinsip 1: kemiripan visual}

Dapat dicapai melalui perletakan masa bangunan dan fasad bangunan yang dibuat meyerupai bentuk objek yang dianalogikan yaitu nasi tumpeng pada Museum Purna Bhakti Pertiwi dan bentuk hewan komodo pada Museum Komodo, dilengkapi dengan ornamen yang melekat didalamnya sebagai penyempurna.

b. Prinsip 2: adanya usaha mentransfer keterangan seolah merupakan hal yang sama

Dapat dicapai melalui pengimplementasian bentuk dasar nasi tumpeng pada Museum Purna Bhakti Pertiwi dan bentuk massa berupa raut hewan komodo pada Museum Komodo.

c. Prinsip 3: tidak menimbulkan intepretasi lain

Prinsip ini dicapai melalui pengoptimalan bentuk bangunan secara keseluruhan.

\section{Kesimpulan}

Dari hasil analisis diatas dapat disimpulkan bahwa Museum Purna Bhakti Pertiwi dan Museum Komodo menerapkan ketiga prinsip arsitektur analogi. Implementasi tiga prinsip arsitektur analogi pada kedua bangunan museum tersebut menghasilkan desain yang unik dan berkarakter seperti menyampaikan pesan tertentu kepada setiap orang yang memandang nya. Dalam implementasinya tidak semerta-merta menjiplak objek akan tetapi terdapat proses analisis yang mendalam sehingga menghasilkan bentuk baru namun masih memiliki kemiripan visual dengan objek yang dijadikan perbandingan. Hasil dari penerapan konsep arsitektur analogi akan selalu berbeda bergantung dari objek apa yang dijadikan analogi atau pebandingan. Indikator penerapan tiga prinsip arsitektur analogi pada kedua museum dapat dilihat pada tabel 1. 
Tabel 1. Indikator Penerapan Konsep Arsitektur Analogi pada Tiga Studi Kasus

\begin{tabular}{|l|l|c|c|c|}
\hline \multirow{2}{*}{ No } & \multirow{2}{*}{ Studi Kasus } & \multicolumn{2}{|c|}{ Prinsip Arsitektur analogi } \\
\cline { 3 - 5 } & Museum Purna Bhakti Pertiwi & Prinsip 1 & Prinsip 2 & Prinsip 3 \\
\hline 1 & Museum Komodo & $\checkmark$ & $\checkmark$ & $\checkmark$ \\
\hline 2 & & $\checkmark$ & $\checkmark$ & $\checkmark$ \\
\hline
\end{tabular}

Sumber: Pribadi, 2020

Keterangan:

Prinsip arsitektur analogi:

Prinsip 1: kemiripan visual

Prinsip 2: upaya mentransfer keterangan seolah merupakan hal yang sama

Prinsip 3: tidak menimbulkan intepretasi lain

\section{Daftar Pustaka}

Abel, C. (1997). Architecture and Identity (An Imprint). Architectural Press.

Broadbent, G. (1973). Design in Architecture. Architecture and the Human Sciences.

Trisjanti, L. I. (2017). Penggunaan Analogi Sebagai Metoda Rancang Arsitektur.

Zarzar, K. M., Guney, A., Lefaivre, L., \& Jong, T. de. (2008). Understanding meaningful environments. Architectural Precedents and the Question of Identity in Creative Design. IOS Press. 